\title{
A MÛSZAKI ÖRÖKSÉG TÁRGYI ÉRTÉKEINEK ELEMZÉSE AZ IDEGENFORGALOMBAN VALÓ HASZNOSÍTÁS ÉRDEKÉBEN
}

\section{THE ANALYSIS OF THE TECHNICAL HERITAGE WITH THE PURPOSE OF ITS TOURISTIC EXPLOITATION}

\author{
Talpas János \\ Babeș-Bolyai Tudományegyetem, Földrajz Kar, 400006 Kolozsvár/Cluj-Napoca, \\ Str.ClinicilorNr.5-7.talpasjanos@gmail.com
}

\begin{abstract}
The material value of the technical heritage occupies in the economical development a role of increasing importance. Therefore presentation and popularization of the technical heritage becomes an important instrument of the economic development. It is a well-known fact that people appreciates a given object in different manner. The present study tries to build up a scale of values from the point of view of the tourism and related services. This will be a useful instrument of decision in emphasizing and restauration of those objects of technical heritage that could be attractive for the large public .The analysis is built on secondary research resources and contains both theoretical and practical elements. Theoretical analysis is completed with a case study.
\end{abstract}

Keywords: tourism, attraction, decision, case study.

\section{Összefoglalás}

A műszaki örökség tárgyi értékei egyre hangsúlyosabb helyet foglalnak el a gazdasági fejlődésben. A gazdasági fejlődés érdekében fontos a müszaki örökségek megjelenítése, ismertetése a nagyközönség számára. Minden ember másképpen értékel egy tárgyat. Jelen tanulmány megkísérel egy értékrendet felállítani az idegenforgalom szemszögéből. Ennek az értékrendnek a célja: segítséget nyújtani azon technikatörténeti tárgyak kiemelésére és felújítására, melyek vonzók a látogatók számára. Az elemzés elméleti és gyakorlati elemeket tartalmaz, szekunder kutatási formára épülve. Az elméleti elemzést egy esettanulmány egészíti ki.

Kulcsszavak: idegenforgalom, attrakció, döntés, esettanulmány.

\section{Bevezetés}

Az ember alkotta tárgy akkor válhat idegenforgalmi attrakcióvá, ha öt feltételt tejesít: legyen különleges funkciója, legyen egyedi, legyen egyénisége, legyen régi [1]. Ötödikként, de nem utolsóként igen fontos a tárgy helyének a szerepe, melynek jelen- tőségét egy korábbi tanulmány tartalmazza [2]. A müszaki örökségvédelem projekt keretében feltárt régi tárgyak elemzésénél a technikai tulajdonságainak leírására összpontosítottunk. A technikai kritérium , $a z a$ feladat, melyre a terméket tervezték' [3]. A tárgyaknak az idegenforgalmi attrakció szerepe nem csak ezektől a tulajdonságoktól függ, nagyon lényeges a pszichológiai 
hatásuk is. A következőképpen utalnak a szakemberek a tárgyak pszichológiai hatására: „A bemutatásra kerülö pszichológiai tételek és feltevések a környezeti és a kognitív pszichológiai témakörben tartoznak" [4]. Jelen tanulmányban eltekintettem a pszichológiai aspektustól, hogy minél átláthatóbbá váljon a tárgynak az idegenforgalomhoz és technikatörténethez kapcsolódó tulajdonsága. Az elemzés megkísérel egy idegenforgalmi értékrendet kialakítani a céltárgyak között. Az elméleti elemzést egy esettanulmány egészíti ki.

\section{2. Értékelési tényezők elemzése}

A turizmus nemzetközi szervezeteinek jelentései és a témával foglalkozó szakértők véleménye szerint napjainkban inkább érezhető a kulturális élmények iránti kereslet [5]. Az értékelési tényezőt a fent említett öt tulajdonság alapján választottam ki. Az értékelésnél 1-25 közötti pontozási értékrendszert alkalmaztam. A pontozási érték alapjául a Bukaresti Turisztikai és Fejlesztési Intézetben (INCDT) kidolgozott, a turisztikai országos területfejlesztési pontozási rendszert választottam [6].

Az elemzésre kerülő tárgyak tulajdonságait alapul véve, ezeket maximálisan 25 pontszámra lehet értékelni. Ezen pontszámok eloszlása az egyes tulajdonságok megítélésében a következőek:

$\begin{array}{ll}\text { - egyediség } & 8 \text { pont; } \\ \text { - különleges funkció } & 5 \text { pont; } \\ \text { - egyéniség } & 4 \text { pont; } \\ \text { - régiség } & 4 \text { pont; } \\ \text { - hely } & 4 \text { pont. }\end{array}$

\subsection{Egyediség}

Egy tárgyról akkor állíthatjuk, hogy egyedi, ha olyan tulajdonsággal rendelkezik, ami más tárgyra nem jellemző. Nagyon kevés a valószínüsége annak, hogy olyan tárgyakat találjunk, mely a fenti követelményt teljes egészében teljesíti. Az egyediséget területi érdekeltség alapján osztályozhatjuk:
1. Helyi (2 pont);

2. Megyei (4 pont);

3. Regionális (6 pont);

4. Országos (8 pont).

Mivel a pontok maximális értéke 8 lehet, az országos jelentőségü tárgyak kapják e rendszerben a legnagyobb pontszámot.

\subsection{Különleges funkció}

A tárgyak a legtöbb esetben a mindennapi életünknek része. A funkcionalitás a tárgyaknak a felhasználtságát igazolja. Ahhoz, hogy ezek a tárgyak idegenforgalmi attrakcióvá váljanak, funkcionalitás szerint a következő értékrendben pontozhatók:

1. Helyi értéket képviseljen (2 pont);

2. Müködjön (1 pont);

3. Látványos legyen (1 pont);

4. Müködése ne legyen hagyományos (1 pont).

A különleges funkció elemzés esetében a pontok összeadódnak.

\subsection{Egyéniség}

Az egyéniség szót a Révai Nagy Lexikon a következőképpen adja meg ,az egyes emberek egyszeri, sajátosan rájuk jellemzö tulajdonságainak összessége”. A tulajdonság a tárgyak esetében is érvényes. A tárgyak egyéniségének az értékrendje kizárólag szubjektív döntés eredménye lehet. A tárgyak egyénisége a személyre tett hatása alapján mérhető. Három kategóriába csoportosíthatjuk a tárgy egyéniségét:

1. Megtekintése után is beszélünk róla és/vagy mondák legendák füződnek hozzá (4 pont);

2. Megtekintésekor leköti a figyelmünket (2 pont);

3. Megnézzük, de közömbös számunkra a tárgy (1 pont).

\subsection{Régiség}

A régiség jellemezhető, mint időben fennmaradt régi tárgy, avagy emlék. A tárgyak régiség alapján való értékeléséhez a következő pontrendszert használhatjuk: 
1. A régiségét írásos dokumentum bizonyítja (4 pont);

2. A régisége szóbeszéddel bizonyítható ( 2 pont);

3. A régisége meghatározatlan jellegü (1 pont). ke 4.

A régiségi pontszám maximális érté-

\subsection{Hely}

A tárgyak akkor jelentenek igazán idegenforgalmi attrakciót, ha a megfelelö helyen a megfelelö személyeknek mutatjuk be. Itt három lehetséges állapotot különböztetünk meg:

1. A tárgy az eredeti helyén található (4 pont);

2. A tárgy más funkciót tölt be, mint az eredeti rendeltetése ( 3 pont);

3. A tárgy helye véletlenszerü (1pont).

A hely pontozása esetében is a maximális elérhető pontszám 4 lehet.

\subsection{Az elemzés kiértékelése}

$\mathrm{Az}$ elemzéskor adott értékeket táblázatba írjuk. Az elért összeg a tárgynak az idegenforgalmi attrakcióként betölthető szerepét fejezi ki.

A végleges pontszám minél közelebb helyezkedik el a maximális 25 ponthoz, a tárgy idegenforgalmi vonzerő értéke annál nagyobb.

\section{Esettanulmány}

Esettanulmányként a kidei idegenforgalomba bevonható, egy kertben található malomkövet elemeztem. A malomkő egy helyi lakos tulajdona, hasznosítási célja nem meghatározott.

Az elemzés lépései.

1. Egyedisége. A malomkő valamikor a helyi malom egyikében müködött. A környéken több malom müködött, melyekben hasonló kövek zúzták a búzát. A környéken, más településeken is találhatunk malomkövet. Ezért ez a ma- lomkő csak helyi egyediséget képviselhet (1 pont).

2. Különleges funkció. Ez a malomkő a helyi lakosok számára egy emlék. Mondhatjuk, hogy egy helyi értéket képvisel (2 pont). A kertben egy kőnek támasztva nem müködhet, és mint ahogyan az 1. ábrán megfigyelhető, nem is annyira látványos.

3. Egyéniség. Szomorú, de amikor megtekintettük sajnálkozva beszéltünk róla. Mindenki egyetértett azzal, hogy jó volna munka közben látni a malomkövet. Munka közben biztosan több egyéniséget sugározna ez a tárgy (1 pont).

4. Régiség. Megkérdezve a malomkerék tulajdonosát, azt állította, hogy ez a hajdani Nyirő-malom malomköve, de írásos dokumentum nincs róla (2 pont).

5. Hely. A malomkövek igazi helye nem a kert. A mi esetünkben semmilyen funkciót nem tölt be a tárgy, a helye véletlenszerü (1 pont).

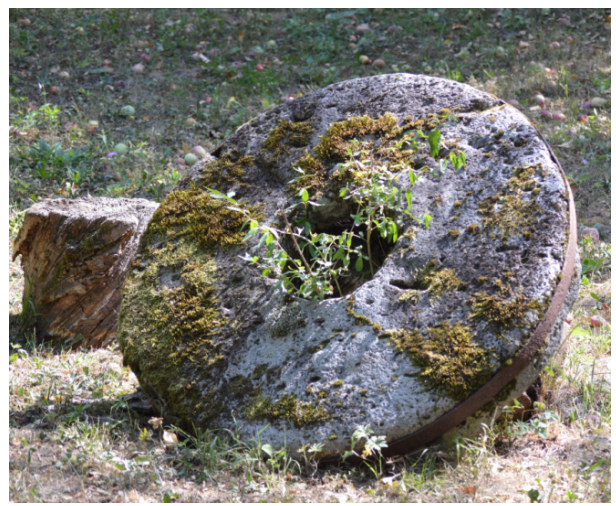

1. ábra. A tanulmányozás tárgya, a kidei malomkö

A tanulmányozott malomkő összpontszáma 7 pont (2. ábra), így csak idegenforgalmi adottsági funkciója van (hiszen nagyon távol áll a 25 ponttól). Anyagi befektetésre és munkára volna szükség ahhoz, hogy ebből a tárgyból idegenforgalmi attrakciót hozzunk létre. 


\begin{tabular}{|c|l|c|c|c|c|c|c|}
\hline Szám & Tárgy & Egyediség & Funkció & Egyéniség & Régiség & Hely & Összesen \\
\hline 1 & malomkő & 1 & 2 & 1 & 2 & 1 & 7 \\
\hline
\end{tabular}

2. ábra. Értékelési tényezők pontozási táblája

\section{Következtetések}

Nehéz eldönteni, hogy érdemes-e egyes tárgyakat bevonni vagy nem az idegenforgalomba. A kialakított pontozási rendszer alkalmazása egy útmutató lehet ezen a téren. Az öt tulajdonság, melyet vizsgáltunk kifejezheti a müszaki örökség tárgyi értékét az idegenforgalomba való hasznosítása érdekében. Ha grafikusan ábrázoljuk az eredményeket, nagyon gyorsan kimutatható a vizsgált tárgynak az idegenforgalomban való hasznosítási lehetősége.

A 3. ábra vizuálisan jól érzékelteti a tanulmányozott tárgy értékelési különbségeit a maximális ponthatárokhoz képest. A grafikonon az is látható, melyek azok a tulajdonságok, melyek a leginkább javításra szorulnak. Az esettanulmány révén, megállapítható, hogy a választott tárgy (a malomkő), még mesze áll attól, hogy idegenforgalmi attrakcióként hasznosíthassuk.

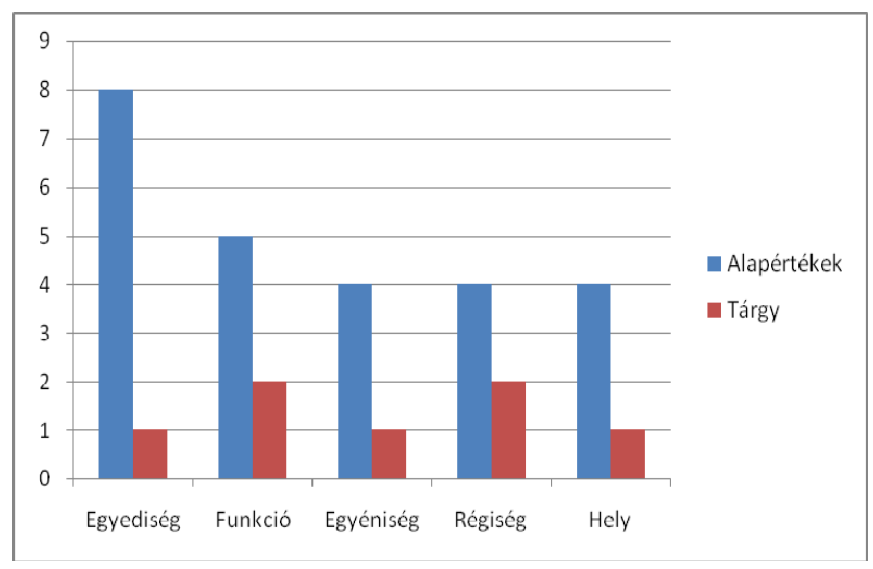

3. ábra. A tárgyi tulajdonságokat bemutató grafikon

\section{Szakirodalmi hivatkozások}

[1] Cocean Pompei, Vlăsceanu Gheorghe, Negoiescu Bebe: Geografia generală a turismului. Meteor Press, Bukarest, 2003. 105.

[2] Talpas János: Müszaki alkotások megörzése az idegenforgalom fejlesztésével. Müszaki tudományos közlemények, EME kiadó, MTK 2. sz. Kolozsvár, 2015.
[3] Izsó Lajos-Becker György: Termékélmény. Akadémiai kiadó, Budapest, 2011. 187.

[4] Puczkó László, Rátz Tamara: Az attrakciótól az élményig. Akadémiai kiadó, Budapest, 2011. 98.

[5] Michalkó Gábor: Turizmológia. Akadémiai kiadó, Budapest, 2012. 184.

[6] Plan de amenajare teritorială națională de turism. Legea 190/2009. 